\title{
LABOR LAW: GENERAL ELECTRIC'S “OVERALL APPROACH” TO BARGAINING HELD A VIOLATION OF GOOD FAITH
}

\section{$\mathrm{I}_{\mathrm{N}} 1947^{1}$ a new vice president at General Electric, Lemuel R. Boul-} ware, introduced an approach to employee and union relations designed to bolster GE's image as a reliable steward of its employees' interests. ${ }^{2}$ The legal propriety of this bargaining philosophy as reflected in the conduct of the company was repudiated in General Elec. Co., ${ }^{3}$ where the NLRB held that GE's implementation of Boulwareism violated the company's duty to bargain in good faith as required by sections 8 (a) (5) ${ }^{4}$ and $8(d)^{5}$ of the Taft-Hartley Act.

Boulwareism is a comprehensive approach to collective bargaining. ${ }^{.}$By means of intensive year-round research, GE attempts to determine what is "right" for its employees in light of business conditions, competition, economic trends, and employee attitudes. ${ }^{7}$ On the basis of facts derived from its own sources and from initial bar-

\footnotetext{
1 Prior to 1947, the employer suffered a series of setbacks in its negotiations with the several unions representing its employees. These were the impetus for the new approach. See Northrup, The Case For Boulwarism, Harv. Bus. Rev., Sept.-Oct. 1963, p. 87; Note, "Boulwareism": Legality and Effect, 76 HARv. L. REv. 807 (1963).

${ }^{2}$ See Note, 76 HARv. L. REv, 807 (1963). The basic approach was to please people with their jobs as the company pleased people with its products. Boulware stated that if the "misunderstanding and disapproval" of the company by the public and its workers was to end, "General Electric management must set out with a firm resolve, first to begin to do whatever was necessary to achieve ultimately the same success in job marketing that we had accomplished in product marketing. In other words, we wanted good job customers and satisfied job customers." Northrup, supra note 1, at 87 (quoting from a GE Employee Relations News Letter). See generally authorities cited note I supra.

${ }^{3} 150$ N.L.R.B. No. 36, 1964 CCH NLRB ๆ 13,651, p. 22030.

"It shall be an unfair labor practice for an employer-

(5) to refuse to bargain collectively with the representatives of his employees . . . ." Labor Management Relations Act (Taft-Hartley Act) \$ 8(a) (5), 61 Stat. 141 (1947), 29 U.S.C. § 158 (a) (5), amending National Labor Relations Act (Wagner Act) § 8 (5), 49 Stat. 452 (1935).

"For the purposes of this section, to bargain collectively is the performance of the mutual obligation of the employer and the representative of the employees to meet at reasonable times and confer in good faith with respect to [appropriate subjects of negotiation] . . . but such obligation does not compel either party to agree to a proposal or require the making of a concession ...." 61 Stat. 142 (1947), 29 U.S.C. \& 158 (d) (1958). (Emphasis added.)

See $1964 \mathrm{CCH}$ NLRB at 22033.

7 Employee attitudes are determined "through independent employee attitude surveys, comments made by employees at informative meetings, direct discussions by supervisors with employees and statements in union publications." Ibid.
} 
gaining sessions with the unions, the company presents a "firm, fair offer" to all unions ${ }^{8}$ which, inter alia, complies with those union demands and proposals it has found to be warranted. ${ }^{\circ}$ Although nothing is reserved for subsequent trading or compromise, ${ }^{10}$ ostensibly the offer is not made on a "take-it-or-leave-it" basis, for the company professes a willingness to alter its proposals whenever sufficient new "information" is presented to indicate that its initial offer was not "right."11 GE's commitment to Boulwareism is strengthened by a policy that no strike, threat of strike, or other economic pressure will cause the company to alter its proposal to an extent deemed "incorrect."12 The GE offer is at all times communicated directly to employees through an elaborate communications system. ${ }^{13}$

The present case arose out of the 1960 negotiations to conclude a national contract between GE and the International Union of Electrical, Radio, and Machine Workers (IUE). An impasse in negotiations resulted in an unsuccessful three-week strike after which the union capitulated and accepted GE's pre-strike offer. ${ }^{14}$ A majority of the NLRB found that GE had violated sections 8 (a) (5) and $8(a)(1)^{15}$ of the Taft-Hartley Act by refusing to bargain in good faith. The following actions were cited by the Board as evidence of this refusal: (1) a failure to furnish certain information when requested by the union during negotiations; (2) attempts, while engaged in national negotiations with the union, to deal separately with locals on matters which were properly the subject of national negotiations, and solicitation of certain locals to abandon or refrain from supporting the strike; (3) GE's presentation of its personal accident insurance proposal to the union on a "take it or leave it"

${ }^{8} \mathrm{GE}$ presents the identical offer to all of the unions with which it deals and also to its non-represented employees. Id. at 22034.

" "General Electric believes that this approach, by ending 'haggling, puts negotiations on a more factual and less emotional basis." Northrup, supra note 1, at 88.

${ }^{10} 1964$ CCH NLRB at 22034.

11 "lt is difficult to determine what type of new information will make GE change its offer since such alterations are infrequent, but apparently such information is limited to facts which can be ascertained objectively, as by mathematical computations." Note, 76 HARv. L. REv. 807, 808 (1963).

121964 CCH NLRB at 22034.

${ }^{18} \mathrm{Ibid}$. Although the avowed purpose of the communications program is to educate employees, this information is presented in a light most favorable to the company and also criticizes union leadership. Note, 76 HArv. L. REv. 807, 808-09 (1963).

14 1964 CCH NLRB at 22032.

15 "IIt shall be an unfair labor practice for an employer] to interfere with, re. strain, or coerce employees in the exercise of the rights [to organize and bargain collectively] guaranted in section $7 \ldots$... 61 Stat. 140 (1947), 29 U.S.C. $\$ 158$ (a) (1) (1958). 
basis; and (4) GE's overall approach to and conduct of collective bargaining. ${ }^{16}$

As a corollary of the duty to recognize bargaining representatives, the federal labor law imposes a duty upon both labor ${ }^{17}$ and management to bargain in good faith. ${ }^{18}$ As a general rule, the "good faith" of an employer is determined from the facts and circumstances of each particular case. ${ }^{10}$ Nevertheless, certain types of specific conduct have been recognized as objective manifestations of a lack of good faith bargaining. ${ }^{20}$ It is well settled that an employer violates section 8 (a) (5) by failing to disclose relevant information to support his contention of economic inability to meet union demands. ${ }^{21}$ In the absence of a justifiable reason why the information should not be furnished, ${ }^{22}$ it must be submitted to the other party within a reasonable time. ${ }^{23}$ It is equally familiar learning that an employer violates

${ }^{10} 1964 \mathrm{CCH}$ NLRB at 22066.

${ }^{17}$ Labor Management Relations Act (Taft-Hartley Act) $\& 8$ (b) (3), 61 Stat. 141 (1947), 29 U.S.C. $§ 158$ (b) (3) (1958).

${ }^{10}$ E.g., NLRB v. Insurance Agents' Int'l Union, 361 U.S. 477, 488 (1960).

19 NLRB v. Truitt Mfg. Co., 351 U.S. 149, 153 (1956); NLRB v. American Nat'l Ins. Co., 343 U.S. 395, 409 (1952); Majure v. NLRB, 198 F.2d 735, 739 (5th Cir. 1952); NLRB v. George P. Pilling \& Son Co., 119 F.2d 32, 37 (3d Cir. 1941); Southern Saddlery Co., 90 N.L.R.B. 1205, 1206 (1950); see Note, Good Faith at the Bargaining Table, 32 TEMP. L.Q. 100, 104 (1958).

${ }^{20}$ See generally Benetar, The Boundaries of the Duty to Bargain in Good Faith Under the N.L.R.A., 15 BAYLOR L. REv. 127 (1963); Cox, The Duty to Bargain in Good Faith, 71 HARv. L. REv. 1401 (1958); Feldesman, The Supreme Court and Collective Bargaining Under the National Labor Relations Act, 13 LAB. L.J. 339 (1962).

${ }_{21}$ See NLRB v. Truitt Mfg. Co., 351 U.S. 149, 152-53 (1956). In NLRB v. Fitzgerald Mills Corp., 313 F.2d 260, 265 (2d Cir.), cert. denied, 375 U.S. 834 (1963), the court said the union is entitled to a presumption that requested wage data is relevant. In determining relevance, the Board and the courts have distinguished between wage data and financial data. Wage data is defined in SMrth \& MERrifield, LAbor RerATIONS LAw 772 (rev. ed. 1960). As a general rule, the employer must produce all wage data requested unless he can show the request is mere harassment or goes beyond the needs of the bargaining agent in performing its duties. Ibid. See NLRB v. Jacobs Mfg. Co., 196 F.2d 680, 683-84 (2d Cir. 1952). See generally Benetar, supra note 20 , at 136 .

32 Depending on the facts of each particular case, not every refusal to meet a union demand will require disclosure of information. NLRB v. Truitt Mfg. Co., supra note 21, at 153-54.

The record in the present case did not indicate that the requested information was irrelevant, $1964 \mathrm{CCH}$ NLRB at 22041, or that production of such information would have imposed an undue burden on the company. Id. at 22042.

${ }^{38}$ In the instant case the Board found substantial evidence to show that timely diligence had not been exercised by GE in furnishing information concerning the cost of various insurance and pension proposals, the number and categories of laid-off and recalled employees in each of several specified units, and the number of employees in each of such units with between $20-25$ years of continuous service with the company. Id. at 22039-43. The union claimed the information was necessary to enable it to appraise the cost of the company's proposals and to determine the number of people who would actually receive benefits from them. Id. at 22039. 
section 8 (a) (5) when he bypasses the union national bargaining committee and attempts to deal directly with locals. ${ }^{24}$ Moreover, the courts have consistently held that a negotiator who enters sessions with a "take it or leave it" attitude violates section 8 (a) (5) although ostensibly he may go through the form of bargaining. ${ }^{20}$ Additionally, the following evidence a violation: meeting and conferring with absolutely no intention of ever reaching an agreement; ${ }^{26}$ direct dealing with employees concerning all or any matters appropriate for collective bargaining with the union; ${ }^{27}$ and extending a unilateral offer to employees concerning a proper subject of collective bargaining before a bona fide impasse has been reached. ${ }^{28}$ In the instant

24 Dealing directly with locals in disregard of the national bargaining committee may constitute unlawful solicitation of employees. Most cases have dealt with the analogous situation of the employer's dealing with individual employees instead of the union. See NLRB v. Herman Sausage Co., 275 F.2d 229 (5th Cir. 1960); Quaker State Oil Ref. Corp. v. NLRB, 270 F.2d 40 (3d Cir. 1959); Federal Dairy Co., I30 N.L.R.B. 1158 (1961), enforced, 297 F.2d 487 (1st Cir. 1962); Crater Lake Mach. Co., 131 N.L.R.B. 1106 (1961). See also Medo Photo Supply Corp. v N.LRB, 321 U.S. 678, 684 (1944).

It was alleged that GE had offered strike-truce proposals to locals which were much more favorable than those offered to the IUE during national negotiations. 1964 CCH NLRB at 22044. However, GE argued that the locals involved were the certified bargaining agents at the particular plants, and thus it was at liberty to deal freely with these locals. Id. at 22045. The NLRB rejected this contention because it found that the history of bargaining at these plants showed that the IUE national committee was to have exclusive bargaining authority during national negotiations. Ibid. Thus the Board found that the action of GE was directed at undermining the IUE's position in violation of $\$ 8$ (a) (5). See The Texas Co., 93 N.L.R.B. 1358, 1360.61 (1951), rev'd on other grounds, 198 F.2d 540 (9th Cir. 1952); Samuel Bingham's Sons Mfg. Co., 80 N.L.R.B. 1612, 1613 (1948). See also J. I. Case Co. v. N.L.R.B., 321 U.S. 332 (1944); Joy Silk Mills, Inc. v. NLRB, 185 F.2d 732 (D.C. Cir. 1950); Cox, supra note 20, at 1408; Sigal, The Evolving Duty To Bargain, 52 GEo. L.J. 379, 385 (1964).

${ }^{23}$ NLRB v. Insurance Agents' Int'1 Union, 361 U.S. 477, 487 (1960); Rapid Roller Co. v. NLRB, 126 F.2d 452, 459-60 (7th Cir.), cert. denied, 317 U.S. 650 (1942).

${ }^{20}$ NLRB v. Insurance Agents' Int'I Union, 361 U.S. 477 (1960); NLRB v. American Nat'1 Ins. Co., 343 U.S. 395 (1952); Vanderbilt Prod., Inc. v. NLRB, 297 F.2d 833 (2d Cir. 1961); NLRB v. Reed \& Prince Mfg. Co., 205 F.2d 131 (Ist Cir.), cert. denied, 346 U.S. 887 (1953); NLRB v. Israel Putnam Mills, Inc., 197 F.2d 116 (2d Cir. 1952); NLRB v. Tower Hosiery Mills, Inc., 180 F.2d 701 (4th Cir.), cert. denied, 340 U.S. 811 (1950); NLRB v. Westinghouse Air Brake Co., 120 F.2d 1004 (3d Cir. 1941); Radiator Specialty Co., 143 N.L.R.B. 350 (1963), modified, 336 F.2d 495 (4th Cir. 1964); California Girl, Inc., 129 N.L.R.B. 209 (I960).

${ }^{2 \pi}$ J.I. Case Co. v. NLRB, 321 U.S. 332 (1944); Medo Photo Supply Corp., v. NLRB, 321 U.S. 678 (1944); Quaker State Oil Ref. Corp. v. NLRB, 270 F.2d 40 (3d Cir. 1959); NLRB v. Century Cement Mfg. Co., 208 F.2d 84 (2d Cir. 1953); Ingalls Shipbuilding Corp., 143 N.L.R.B. 712 (1963); Samuel Bingham's Sons Mfg. Co., 80 N.L.R.B. 1612 (1948). Compare NLRB v. Penokee Veneer Co., 168 F.2d 868 (7th Cir. 1948); The Texas Co., 93 N.L.R.B. 1358, 1360 (1951), rev'd on other grounds, 198 F.2d 540 (9th Cir. 1952).

${ }^{23}$ See NLRB v. Crompton-Highland Mills, Inc., 337 U.S. 217 (1949); May Dept. Stores Co. v. NLRB, 326 U.S. 376 (1945); Joy Silk Mills, Inc. v. NLRB, 185 F.2d 732 (D.C. Cir. 1950), cert. denied, 341 U.S. 914 (1951).

Other forms of conduct may evidence a refusal to bargain in good faith: sec, e.g., 
case, the NLRB made findings ample to sustain a decision based upon any one of these familiar examples.

The significance of General Elec. Co., however, was the Board's holding that even without the aforementioned factors, GE's overall approach to and conduct of collective bargaining was sufficient to constitute a refusal to bargain in good faith. ${ }^{29}$ It found that GE's communications campaign and "its conduct at the bargaining table" evidenced a "take-it-or-leave-it" attitude. ${ }^{30}$ The censure of Boulwareism was not predicated upon an assessment of the employer's specific techniques of bargaining ${ }^{31}$ but rather upon a review of the totality of conduct during the course of the negotiations. ${ }^{32}$ It would appear from the implications of the majority ${ }^{33}$ and the observations of the concurring opinion ${ }^{34}$ that the Board considers the traditional "ask-and-bid" technique essential to a good faith approach to collective bargaining. ${ }^{35}$ Although the Board expressly disclaimed any

Fiberboard Paper Prod. Corp. v. NLRB, 379 U.S. 203 (1964) (meeting and conferring but a refusal to negotiate concerning a mandatory subject of bargaining); NLRB v. Katz, 369 U.S. 736, 743 (1962) (a fat refusal to meet and confer with the union); NLRB v. Borg-Warner Corp., 356 U.S. 342 (1957) (insistence to the point of impasse concerning a non-mandatory subject of bargaining); $H$. J. Heinz Co. v. NLRB, 311 U.S. 514 (1940) (refusal to commit to writing what has been voluntarily agreed upon); Insulating Fabricators, Inc., 144 N.L.R.B. 1325 (1963), enforced, 338 F.2d 1002 (4th Cir. 1964) (employer's failure to provide a bargaining representative who can meet at reasonable times).

201964 CCH NLRB at 22066. This is not the first case in which the Board has said that bad faith may be found even though there is no contemporaneous unlawful conduct. See George Groh \& Sons, I4I N.L.R.B. 931, 939-40 (1963), enforced, 329 F.2d 265 (10th Cir. 1964); Snow v. NLRB, 134 N.L.R.B. 709 (1961), enforced, 308 F.2d 687, 693 (9th Cir. 1962).

${ }^{30} 1964 \mathrm{CCH}$ NLRB at 22066.67.

${ }^{31}$ Id. at 22068. Thus, the Board stated that GE would not be required to cease its fact-finding procedure or "specific methods of formulating proposals." Ibid.

${ }^{2} 2$ Ibid.

33 “'This 'bargaining approach' [of GE] undoubtedly eliminates the 'ask-and-bid' or 'auction' form of bargaining, but in the process devitalizes negotiations and collective bargaining and robs them of their commonly accepted meaning. 'Collective bargaining' as thus practiced is tantamount to mere formality and serves to transform the role of the statutory representative from a joint participant in the bargaining process to that of an advisor." Ibid.

'The term 'bargain collectively' as used in the Act 'has been considercd to absorb and give statutory approval to the philosophy of bargaining as worked out in the labor movement in the United States." " Id. at 22067 n.16.

3t "In effect I read the majority opinion to hold that the Act so regulates a party's choice of techniques in collective bargaining as to make unlawful an advance decision, concerning the position from which a party is unwilling to retrcat." Id. at 22069 . The majority of the Board answered that the concurring member "misread" its holding in asserting that its decision was based on GE's technique of bargaining rather tban on an assessment of its overall conduct. Id. at 22068.

${ }^{35}$ Since the employer's communications campaign was probably sufficient to sustain the finding of a refusal to bargain in good faith, see notes $24,27-28$ supra and accom- 
intention to freeze methods of collective bargaining into an inflexible mold ${ }^{36}$ arguably it has done just that. The majority opinion places so high a premium on give and take in negotiations that it seemingly declares initial candor inconsistent with good faith bargaining; consequently, this decision may compel employers and unions to waste time and money in needless preliminary bickering before they feel free to state their positions clearly. ${ }^{37}$

Nevertheless, both labor and management might prefer a statement at the start of negotiations of the maximum which each side will compromise, and yet maintain a bona fide desire to negotiate and reach an agreement. ${ }^{38}$ To characterize such an approach to bargaining as "take-it-or-leave-it" would be contrary to the Supreme Court's definition of that phrase. ${ }^{39}$ At the very least, the Board should clarify its decision to furnish employers with a standard by which to appraise their future conduct.0

panying text, the only purpose served in finding a "take-it-or-leave-it" attitude was to enable the Board to proscribe the "firm, fair offer."

${ }^{88} 1964$ CCH NLRB at 22067.

${ }^{37}$ See Philip Carey Mfg. Co. v. NLRB, 331 F.2d 720 (6th Cir.), cert. denied, 57 L.R.R.M. 2307 (1964). In that case, after eleven negotiation sessions, the company took a firm position and would not budge from it. The Board and court found no violation of $\S 8(a)(5)$. "As the Board pointed out, July 28 was the eleventh meeting between the parties and the Company was entitled to take a definite position at that time." Id. at 725. It must be pointed out, however, that the Board in the Carey case limited it to its facts. It expressly denied that it was passing on any technique of bargaining, such as Boulwareism in general. Philip Carey Mfg. Co., 140 N.L.R.B. 1103, 1104 n.2 (1968).

Compare NLRB v. American Nat'l Ins. Co., 843 U.S. 895 (1952) where it is stated that "the Act does not encourage a party to engage in fruitless marathon discussions at the expense of frank statement and support of his position." Id. at 404.

${ }^{3 s}$ Thus, query whether the Board would endorse the definition of "lawful" hard bargaining suggested by the General Counsel of the IUE? "Lawful hard bargaining occurs, we submit, when an employer or a union refuses to change its position after it (1) meets and confers at reasonable times and demonstrates a willingncss to enter into an agreement, (2) submits its proposals to the give and take of searching discussion, (3) freely states its reasons for the positions it takes, (4) discloses any relevant information necessary to support or evaluate its positions, and (5) states and discusses reasons as well as information relevant to its rejection of the proposals on the other side." Sigal, supra note 24 , at 388.

${ }^{30}$ See note 25 supra. "Collective bargaining, then, is not simply an occasion for purely formal mcetings between management and labor, while each maintains an attitude of 'take it or leave it'; it presupposes a desire to reach ultimate agrecment, to enter into a collctive bargaining contract." NLRB v. Insurance Agents' Union, 861 U.S. 477, 485 (1960).

${ }^{20}$ The clear existence of alternative grounds for the Board's decision, see text at notes 21.28 supra, would appear to render the somewhat confusing condemnation of GE's overall approach to bargaining dictum. "The fundamental issues in this case have been obscured by slogans and shibboleths which have understandably led my colleagues into deciding issues which in my judgment are not presented for decision." $1964 \mathrm{CCH}$ NLRB at 22068 (concurring opinion). 
One such standard was suggested in passing by the Board. If, from an examination of the overall conduct of the employer, it appears that the company has set itself up as a quasi-administrative body having the responsibility for determining, rather than proposing, wages and other working conditions for its employees and other working conditions for its employees and has relegated the union to a position as spokesman for an "interested group," then this would be a strong indication of the employer's disregard of its duty to engage in collective bargaining. ${ }^{41}$ If the company operates in this manner, no other specific violation or occurrence of contemporaneous unlawful conduct would be required to sustain a finding of a violation of section 8 (a) (5).

t.c.c.

41 '[W]hile the Board cannot force an employer to make a 'concession' on any specific issue or to adopt any particular position, the employer is obliged to make some reasonable effort in some direction to compose his differences with the union . . .." NLRB v. Reed \&: Prince Mfg. Co., 205 F.2d 131, 134-35 (1st Cir.), cert. denied, 346 U.S. 887 (1953); see NLRB v. Herman Sausage Co., 275 F.2d 229 (5th Cir. 1960); NLRB v. Jacobs Mfg. Co., 196 F.2d 680, 683 (2d Cir. 1952); Rapid Roller Co. v. NLRB, 126 F.2d 452, 459-60 (7th Cir.), cert denied, 317 U.S. 650 (1942); NLRB v. Westinghouse Air Brake Co., 120 F.2d 1004, 1006 (3d Cir. 1941); Radiator Specialty Co., 143 N.L.R.B. 350, 368 (1963); modified, 336 F.2d 495 (4th Cir. 1964); Cox, supra note 20, at 1412; Note, "Boulwareism": Legality and Effect, 76 HARv. L. Rev. 807, 812-13 (1963); Comment, Good Faith at the Bargaining Table, 32 TEMP. L.Q. 100, 103 (1958). Thus, it is submitted that the "firm, fair offer" alone was not indicative of a refusal to bargain in good faith, but in the instant case it was GE's absolute refusal to permit the union to play an active role in adjusting differences between labor and management which constituted a violation of $\& 8(a)(5)$. 